\title{
Cnemidophorus vacariensis Feltrim and Lema, 2000 (Squamata: Teiidae): A new record for the state of Paraná, southern Brazil
}

\author{
Gilberto Alves de Souza Filho \\ Instituto de Tecnologia para o Desenvolvimento - LACTEC. Centro Politécnico da Universidade Federal do Paraná. CP 19067. CEP 81531-980. \\ Curitiba, PR, Brazil. \\ E-mail: gilbertoasfilho@yahoo.com.br
}

\begin{abstract}
Cnemidophorus vacariensis (Teiidae) is endemic to southern Brazil, occurring in the states of Rio Grande do Sul, Santa Catarina and Paraná. In the state of Paraná, this species has only been recorded in the municipality of Candói, centralsouth region of the state. Herein, a new record of one individual of $C$. vacariensis is reported for the municipality of Tibagi, located in the central-eastern region of Paraná. This record represents the northern limit of distribution of the species.
\end{abstract}

Cnemidophorus Wagler, 1830 is a genus of teiid lizards, widely distributed in Americas, from the USA, in North America, to Argentina, in southern South America (Reeder et al. 2002; Harvey et al. 2012). Recently, Harvey et al. (2012) proposed changes in teiid taxonomy and created new genera to allocate some Cnemidophorus species. Giugliano et al. (2013) contested these new taxonomic arrangements, considering them premature (see Giugliano et al. 2013). The proposal presented by Giugliano et al. (2013) is adopted in this study, maintaining the taxonomic position of the genus Cnemidophorus previous to Harvey et al. (2012). The Cnemidophorus lacertoides group is a species complex currently composed of four species: Cnemidophorus lacertoides Duméril and Bibron, 1839, C. leachei Peracca, 1897, C. serranus Cei and Martori, 1991, and C. vacariensis Feltrim and Lema, 2000, distributed through Argentina, southern Brazil and Uruguay (Cei 1993; Feltrim and Lema 2000; Borteiro et al. 2013).

Cnemidophorus vacariensis is distinguished from the other species of the lacertoides group by presenting dorsal color pattern with longitudinal stripes constituted of light spots, and by presenting the largest number of dorsal scale rows, both in longitudinal and transverse rows (Feltrim and Lema 2000). It is endemic to southern Brazil, occurring in the states of Rio Grande do Sul, Santa Catarina and Paraná (Feltrim and Lema 2000; Di-Bernardo et al. 2003; Bérnils et al. 2004; Stahnke et al. 2006; Ghizoni Jr et al. 2009; Caruccio et al. 2010). This species inhabits rocky outcrops in high elevation grasslands of the Araucaria Plateau (Di-Bernardo et al. 2003; Bérnils et al. 2004; Caruccio et al. 2010). In the state of Paraná, C. vacariensis has been recorded only in the municipality of Candói, central-south region of the state (Bérnils et al. 2004). There are also unconfirmed reports of the occurrence of the species around the city of Guarapuava, neighboring municipality of Candói (Bérnils et al. 2004; Morato 2010).

During a faunal inventory for the evaluation of environmental impact as part of a project for the energy sector in the municipality of Tibagi, central-eastern region of the state of Paraná, in the Fazenda Pinheirinhos, we found one individual of Cnemidophorus vacariensis in the afternoon of January 30 2013. This individual was under a stone and, due to absence of collection permits, it could not be collected, and was only recorded by photographs (Figure 1). The identification was carried out at the site and agrees with the original description of the species (Feltrim and Lema 2000). As described, the shields of the head present brown coloration dorsally and, laterally, the lower margin is light; dorsal color brown, with three dorsolateral longitudinal stripes composed by light spots on each side of the body, a paravertebral stripe that began near the postparietal reaching the tail, and two other stripes that begin behind the eyes and continue along the limbs; between these stripes, are irregular dark brown blotches; vertebral region is light brown, bounded by small light blotches; the dorsal of the anterior and posterior limbs is brown with three stripes composed of light spots, with dark brown blotches between them; tail dorsally brown with small light and dark brown spots.

The site of this record is characterized by open environment with presence of grasses, shrubs and many rocky outcrops (2438'04'"S, 50¹3'50"W; $1180 \mathrm{~m}$ elevation; Figure 2). Although preserved, the area is used for cattle ranching, with the presence of many animals.

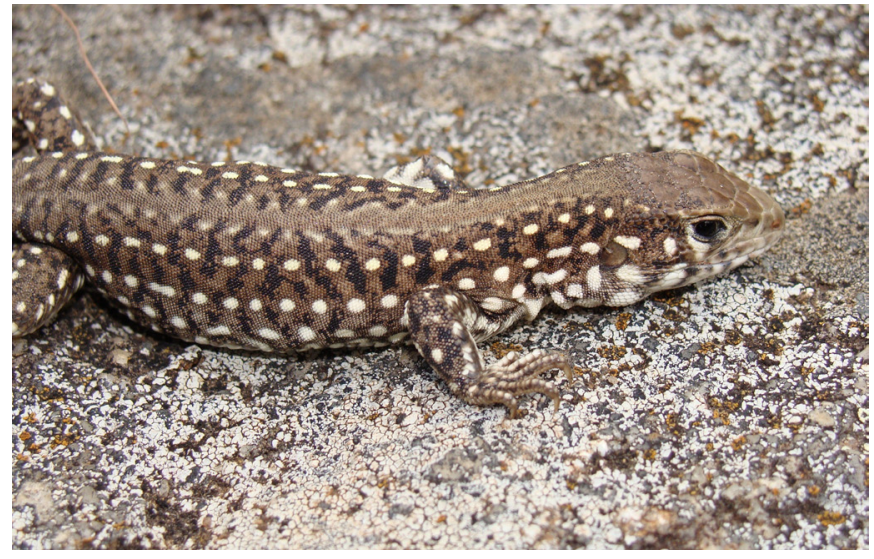

FIGURE 1. Living adult specimen of Cnemidophorus vacariensis found in the municipality of Tibagi, state of Paraná, southern Brazil. 


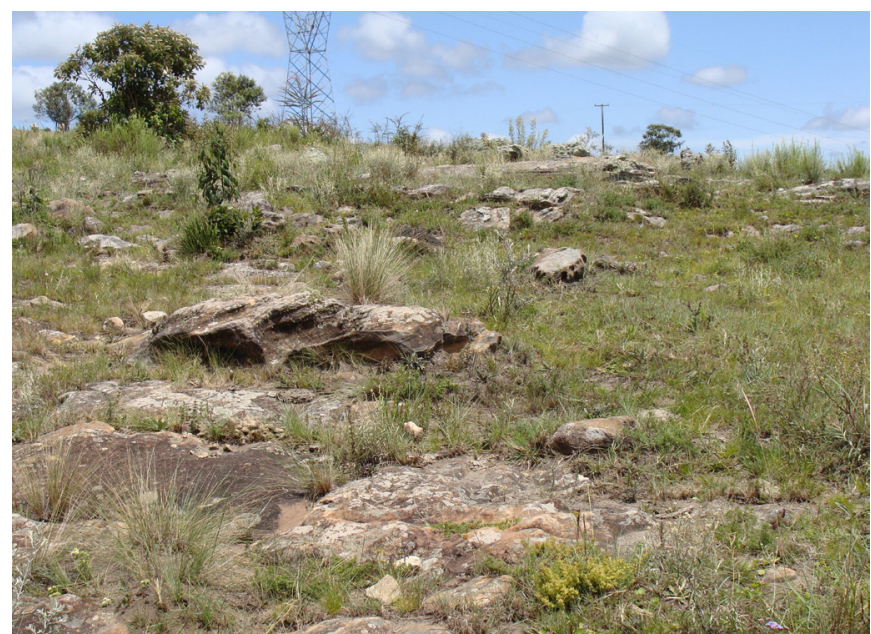

FIGURE 2. Site of the record of Cnemidophorus vacariensis in Fazenda Pinheirinhos, municipality of Tibagi, state of Paraná, southern Brazil.

Cnemidophorus vacariensis is threatened of extinction in the three states where it occurs, and also at a national level (Di-Bernardo et al. 2003; Bérnils et al. 2004; Martins and Molina 2008; CONSEMA 2011). In the state of Paraná, and in Brazil, this species has been categorized as "Vulnerable" (Bérnils et al. 2004; Martins and Molina 2008). Among the main threats to $C$. vacariensis are agricultural expansion, cattle ranching, the use of fire in the preparation of pastures, and the planting of exotic species (Bérnils et al. 2004; Morato 2010). Due to its distribution not yet being completely known, and to threats to its natural environment, $C$. vacariensis has been assessed as "Data Deficient" at a global level (Morato 2010).

Both sites where Cnemidophorus vacariensis has been found in the state of Paraná are dominated by monoculture plantations or cattle ranching. However, the Fazenda Pinheirinhos is a few miles from the Parque Estadual do Guartelá, a conservation unit that presents a similar natural physiognomy to the area, with a predominance of grasslands with many rocky outcrops. Likewise, the Candói site is near the Parque Estadual de Santa Clara, which also presents environments favorable for the occurrence of the species. The presence of $C$. vacariensis in those conservation units can be expected, as well as in other areas of the state, near or between the municipalities of Tibagi and Candói, demonstrating the need for more studies in the region. The present record represents the second site of occurrence of Cnemidophorus vacariensis in Paraná, extending the known geographic distribution of this species $c a .200 \mathrm{~km}$ northeast from the closest reported site, and also represents the northernmost limit of distribution of the species (Figure 3).

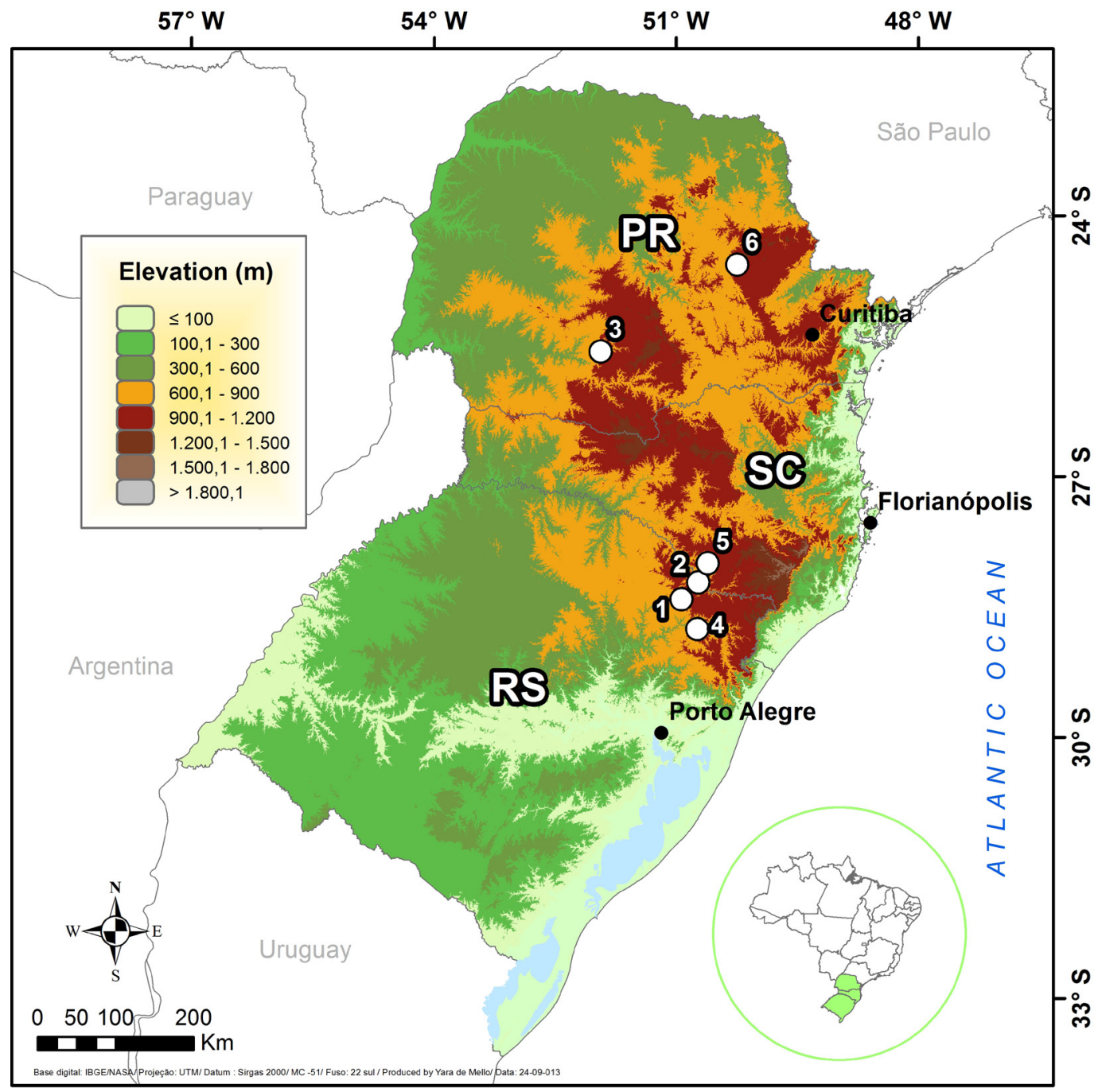

FIGURE 3. Geographic distribution of Cnemidophorus vacariensis: 1. Vacaria (Feltrim and Lema 2000), 2. Bom Jesus (Di-Bernardo et al. 2003; Caruccio et al. 2010), in the state of Rio Grande do Sul (RS); 3. Candói (Bérnils et al. 2004), in the state of Paraná (PR); 4. São Francisco de Paula (Stahnke et al. 2006), in the state of Rio Grande do Sul (RS); 5. Capão Alto (Ghizoni Jr et al. 2009), in the state of Santa Catarina (SC); 6. Tibagi (present study), in the state of Paraná (PR). 
ACKNOWLedgments: I am grateful to Robson O. E. Hack and Patricia D. Borges for help in field; to Taim Cade Brasil Indústria e Comércio de Equipamentos Ltda for authorization and incentive to scientific publication; to Anne T. D. Baldisseri for the English revision; to Yara R. de Mello for the preparation of the distribution map. I am indebted to Federico J. Arias, Lilian G. Giugliano and Pedro M. S. Nunes for text revisions and relevant comments on the manuscript.

\section{Literature Cited}

Bérnils, R.S., J.C. de Moura-Leite and S.A.A. Morato. 2004. Répteis; p. 497535 In S.B. Mikich and R.S. Bérnils (ed.). Livro Vermelho da Fauna Ameaçada no Estado do Paraná. 2ª ed. Curitiba: Instituto Ambiental do Paraná.

Borteiro, C., F. Kolenc, C. Prigioni, M.L. Lyra and D. Baldo. 2013. A lost species or the loss of stripes? The case of Contomastix lizards from Cabo Polonio, Uruguay, with observations on C. lacertoides (Duméril \& Bibron) and Cnemidophorus grandensis Cope (Squamata, Teiidae). Zootaxa 3620(2): 245-259.

Caruccio, R., R.C. Vieira and L. Verrastro. 2010. Microhabitat use by Cnemidophorus vacariensis (Squamata: Teiidae) in the grasslands of the Araucaria Plateau, Rio Grande do Sul, Brazil. Zoologia 27(6): 902908.

Cei, J.M. 1993. Reptiles del noroeste, nordeste y este de la Argentina. Herpetofauna de las selvas subtropicales, Puna y Pampas. Monografie dei Museo Regionale di Scienze Naturale di Torino 14: 1-949.

CONSEMA. 2011. Resolução Consema $n^{\circ}$ 002, de 06 de dezembro de 2011. Reconhece a Lista Oficial de Espécies da Fauna Ameaçadas de Extinção no Estado de Santa Catarina e dá outras providências. Diário Oficial de Santa Catarina, 20 de dezembro de 2011: 2-8.

Di-Bernardo, M., M. Borges-Martins and R.B. Oliveira. 2003. Répteis; p. 165-188 In C.S. Fontana, G.A. Bencke and R.E. Reis (ed.). Livro vermelho da fauna ameaçada de extinção no Rio Grande do Sul. Porto Alegre: EDIPUCRS.
Feltrim, A.C. and T. Lema. 2000. Uma nova espécie de Cnemidophorus Wagler, 1830 do Estado do Rio Grande do Sul, Brasil (Sauria, Teiidae). Biociências 8(1): 103-114.

Ghizoni Jr, I.R., T.S. Kunz, J.J. Cherem and R.S. Bérnils. 2009. Registros notáveis de répteis de áreas abertas naturais do planalto e litoral do Estado de Santa Catarina, sul do Brasil. Biotemas 22(3): 129-141.

Giugliano, L.G., C.C. Nogueira, P.H. Valdujo, R.G. Collevatti and G.R. Colli. 2013. Cryptic diversity in South American Teiinae (Squamata, Teiidae) lizards. Zoologica Scripta 42: 473-487.

Harvey, M.B., G.N. Ugueto and R.L. Gutberlet Jr. 2012. Review of teiid morphology with a revised taxonomy and phylogeny of the Teiidae (Lepidosauria: Squamata). Zootaxa 3459: 1-156.

Martins, M. and F.B. Molina 2008. Répteis: panorama geral dos répteis ameaçados do Brasil; p. 327-334 In A.B.M. Machado, G.M. Drummond and A.P. Paglia (ed.). Livro vermelho da fauna brasileira ameaçada de extinção. Volume II. Belo Horizonte: Fundação Biodiversitas.

Morato, S.A.A. 2010. Cnemidophorus vacariensis. In IUCN 2012. IUCN Red List of Threatened Species. Version 2012.2. Electronic Database accessible at http://www.iucnredlist.org/. Captured on 27 March 2013.

Reeder, T.W., C.J. Cole and H.C. Dessauer. 2002. Phylogenetic relationships of whiptail lizards of the genus Cnemidophorus (Squamata: Teiidae): a test of monophyly, reevaluation of karyotypic evolution, and review of hybrid origins. American Museum Novitates (3365): 1-61.

Stahnke, L.F., G.E.F. Silva, R.S. Reguly and I.F. Machado. 2006. Novo registro de Cnemidophorus vacariensis para o estado do Rio Grande do Sul, Brasil (Sauria, Teiidae). Biociências 14(1): 91-92.

RECEIVED: March 2013

ACCEPTED: October 2013

Published Online: December 2013

EDITORIAL RESPONSIBILITY: Pedro M. S. Nunes 